\title{
ISMERETEK A SZELEKTÍV MUTIZMUSRÓL
}

\section{Szerzők:}

Schéder Veronika

Debreceni Egyetem (Magyarország)

Első szerző e-mail címe: veronika.scheder@gmail.com

\section{Lektorok:}

Szabó Edina

Szabolcs-Szatmár-Bereg Megyei Kórházak és Egyetemi Oktatókórház (Magyarország)

Mező Katalin

Debreceni Egyetem (Magyarország)

Schéder Veronika (2018): Ismeretek a szelektív mutizmusról - pedagógusoknak. Különleges Bánásmód, IV. évf. 2018/4. szám, 45-57. DOI 10.18458/KB.2018.4.45

\begin{abstract}
ABSZTRAKT
Szülök, pedagógusok, de gyakran még szakemberek (pszichológusok, terapeuták) is értetlenül állnak egy rejtélyes kommunikációs zavarral szemben, amelyet a szakirodalom szelektiv mutizmusként definiál. A szelektiv mutizmussal élö gyermekek ugyanis idegenek elött (föként az óvodában és az iskolában) senkivel sem beszélnek, holott beszédfejlödésük ép, és otthoni környezetben, a szüleikkel és családtagjaikkal rendesen kommunikálnak. (Ritkábban, de ennek ellenkezöje is elöfordulhat: egyes családtagjaikkal - például a szülökkel, vagy csak az egyik szülövel - nem beszélnek, az intézményi nevelés szinterein azonban igen.) Ha még az óvodában annyira nem is, de az iskolában már nagy gondot okoz ez a probléma. Hiszen nemcsak a szülöknek, de a pedagógusoknak sincsenek eszközeik a nembeszélö gyerekek speciális kezeléséhez, kommunikációs gátjaik áthidalásához, és ez megneheziti a nevelésoktatás folyamatát. Az alábbi tanulmányban annak jártunk utána, vajon milyen okok vezethetnek a szelektív mutizmus kialakulásához, s e háttérinformációk ismeretében hogyan tudnak (tudnak-e) a szülök és a segítö szakemberek (ideértve a pedagógusokat is) a tünetek áthidalásában, feloldásában eredményesen együttmüködni.
\end{abstract}

Kulcsszavak: szelektív mutizmus, szociális fóbia, beszédviselkedés-minta, szorongás, dependenciazavar

Diszciplína: pszicholingvisztika

\section{ABSTRACT}

\section{INTRODUCTION INTO SELECTIVE MUTISM}

Parents, teachers, and often even experts (including psychologist and therapists) are baffled by a mysterious communicative disorder, which is defined by relevant literature as "selective mutism." Children living with this disorder refuse to speak to anyone (especially in kindergarten and in school), in spite of the fact that their vocal development is unharmed and they communicate with their parents and other family members normally at home. This disorder may not cause problems in kindergarten but all the more so in school. Pedagogues lack any tools for the special treatment of non-speaking children, in order to help them overcome their communicative barriers, and this raises several obstacles in the teaching process. In this paper, the reasons leading to selective mutism are discussed besides the question whether, in cognisance of the background knowledge, supporting experts (including teachers) can, if at all, cooperate successfully in bridging and resolving symptoms. 
Keywords: selective mutism, social phobia, vocal behaviour pattern, anxiety, dependency disorder

Discipline: psycholinguistics

Szülök, pedagógusok, de gyakran még szakemberek (pszichológusok, terapeuták) is értetlenül állnak egy rejtélyes kommunikációs zavarral szemben, amelyet a szakirodalom szelektív mutizmusként definiál. A szelektív mutizmussal élő gyermekek ugyanis idegenek elött (főként az óvodában és az iskolában) senkivel sem beszélnek (holott beszédfejlődésük ép, és otthoni környezetben, a szüleikkel és családtagjaikkal rendesen kommunikálnak). Ritkábban ennek az ellenkezöje is elöfordulhat: egyes családtagjaikkal - például a szülökkel, vagy csak az egyik szülövel - nem beszélnek, az intézményi nevelés szinterein azonban igen. Ha még az óvodában annyira nem is, de az iskolában már nagy gondot okoz ez a probléma. Nemcsak a gyermekek társas beilleszkedését nehezíti meg, hanem tanulmányi elömenetelüket is befolyásolja az állapotuk: a beszédkészség gyakorlása nélkül egy idő után mentális képességeik fejlődése is érintetté válhat. A szülőknek/nevelőknek, pedagógusoknak nincsenek eszközeik a nembeszélö gyerekek speciális kezeléséhez, kommunikációs gátjaik áthidalásához, és ez megnehezíti a számonkéréseket, az értékelést, vagy akár osztályközösségszinten az oktatómunka folyamatát. Az alábbi tanulmányban annak jártunk utána, vajon milyen okok vezethetnek a szelektív mutizmus kialakulásához, s e háttérinformációk ismeretében hogyan tudnak (tudnak-e) a szülők és a segítő szakemberek (ideértve a pedagógusokat is) a tünetek áthidalásában, feloldásában eredményesen együttmüködni.

\section{A SZELEKTÍV MUTIZMUS FOGALMI MEGHATÁROZÁSA, TÜNETEI}

A szelektív - korábbi elnevezéssel elektív - mutizmust a gyermekpszichiátria 1934 óta tartja számon önálló betegségként. A Betegségek Nemzetközi Osztályozása (BNO) a szocializáció jellegzetesen gyermek- és serdülőkorban kezdődő zavarai közé sorolja, és úgy határozza meg, mint ami: „Markáns, emocionálisan meghatározott szelektivitás a beszédben, a gyermek bizonyos helyzetekben jó beszédképességről tesz tanúságot, míg más helyzetekben nem beszél. A zavar rendszerint társul jelentős személyiségvonásokkal, mint szociális szorongás, visszahúzódás, (túl)érzékenység és ellenkezés (BNO-10 zsebkönyv 2004, 160).” BNO-10 kódja F94.0, amit az amerikai eredetü felosztás, a DSM-5 (a mentális rendellenességek diagnosztikai és statisztikai kézikönyvében) a szorongásos zavarok közé sorol, s diagnosztikai kritériumának tartja, „ha egy személy következetesen nem tud megszólalni konkrét társas helyzetekben legalább egy hónapon át, és ez nehézségeket okoz tanulmányai vagy munkahelyi kötelezettségei teljesítése során (Nussbaum, 2013, 107)". A magyar gyermekpszichiátriai szakirodalom a szelektív mutizmust leginkább a kapcsolatteremtési zavarok kóros formájának nevezi, lényegében a beszédszituációhoz kötődő fóbiának (Tringer, 2010). Kiemeli, hogy bár a kórkép hátterében a beszédfejlődés enyhe késése, zavara a legtöbb esetben kimutatható, az érintettek már kialakult nyelvi készségei épek, s inkább a családra jellemző egyfajta túlzott zártság és protektivitás, melynek nyomán a szelektív mutista gyermek személyiségében a fóbiás szorongásosság tünetei bontakoznak ki.

Összességében egy olyan, súlyosnak tünő, ám organikus eltérés nélküli, jelen tudásunk szerint pszichés eredetünek tartott állapotról van szó, amely bizonyos szempontból egyébként komoly differenciáldiagnosztikai problémát vet fel (vö. Gósy, 2005). Gyakori ugyanis, hogy a kommunikációs rendellenességhez társuló egyéb tünetek (mint pl. depresszió, viselkedészavar, alvás- és evészavarok, olykor a szobatisztaság zavarai) is olyan intenzívek, hogy jogosan merülhet fel a kérdés: vajon az együtt jelentkező tünetek sorában melyik az ok 
és melyik az okozat? A speciális nyelvi viselkedés jellemzőinek feltérképezése tehát fontos része a diagnosztikai protokollnak.

A szelektív mutista gyermekek általában csak otthon, a családtagokkal beszélnek, de az óvodában, iskolában, idegenekkel már nem. Egyesek idegenek jelenlétében a szükebb család tagjaival sem képesek szóba állni. Vannak, akik legalább suttogva hajlandók beszélni, míg mások nonverbálisan kommunikálnak, de a legsúlyosabb esetekre az jellemző, hogy az óvodában/iskolában a beszéddel együtt szinte minden életmegnyilvánulásukat visszafogják, vegetatív szükségleteiket sem képesek kielégíteni (pl. evés, ivás, WC-használat). Súlyosbítja a helyzetet, hogy az idő elörehaladtával a szelektív mutista gyermekek mentális fejlödése is érintetté válhat: mivel nem beszélnek, nem gyakorolják a megismerő tevékenységeket, a szociális képességeiket, így azok nem is fejlődhetnek (Sarkadi és Kóri, 2005).

Sokak szerint a szelektív mutizmus az egyik legrejtélyesebb kommunikációs zavar (Ranschburg, 2005). A fellépö tüneteknek nincs bevezető szakasza, a környezet számára általában úgy tünik, mintha hirtelen, minden azonosítható ok vagy előzmény nélkül jelentkeznének (statisztikailag többnyire 3-4, ill. 5-6 éves kor környékén). A korábban már jó szinten beszélő gyermek ilyenkor - szinte egyik pillanatról a másikra - bizonyos helyzetekben vagy feltételek között nem szólal meg. Önmaga „dönti el”, kit vesz be kommunikációs körébe. Alapvetően visszautasítja a beszédet, ugyanakkor kiválasztott személyekkel, helyzetekben vagy időpontokban kommunikál (tehát fontos összetevője állapotának, hogy beszédprodukciója és beszédmegértése továbbra is ép). A szelektív mutista gyermek következetesen tartja ezt a választott némaságát, ebből kizökkenteni nem lehet, sem utasítással, sem kéréssel (Gósy, 2005; Hernádi, 2006; Illyés, 2000).

Viselkedésükre jellemzővé válhat, hogy csecsemőknek kijáró elönyökkel kárpótolják magukat. Mivel a családon kívül mással nincs kapcsolatuk, a család súlyosan terhelt, különösen az édesanyával való kapcsolat, ami nemegyszer kölcsönös agresszióval telítődik. A félénkség és a visszahúzódó viselkedés mellett ugyanis makacs, engedetlen, passzív-agresszív karakter azonosítható ezeknél a gyerekeknél - talán épp ez a makacsság az, ami akadályozza őket abban is, hogy a nembeszélésüket feladják (Sarkadi és Kóri, 2005).

\section{A SZELEKTÍV MUTIZMUS FELTÉTELEZETT OKI HÁTTERE}

A tünetegyüttes kialakulásával (oki hátterével) kapcsolatos vélemények sokfélék. Az alábbiakban felsoroljuk a legjellemzőbb elméleteket:

- A pszciholingvisztikai szakirodalmak leírják ezeknek a gyermekeknek a beszédtől való félelmét. A beszédtől való félelem azonban más félelmekhez is kötődhet. Viselkedésük így tulajdonképpen egyfajta védekezési mechanizmussá válik: a beszéd tagadásával valójában a számukra nehéz és megoldhatatlannak látszó körülményeket igyekeznek elkerülni. A szelektív mutizmust ilyenformán a szociális fóbia egyik megnyilvánulási formájának is nevezhetnénk. A nemzetközi kutatási eredmények azt igazolják, hogy a szelektív mutista gyermekek családjában jelentősen magasabb a szociális fóbia (és a szelektív mutizmus) előfordulása, tehát a társas helyzetektől való szorongás átöröklődhet, ill. áttevődhet a gyermekre (Black és Uhde, 1992).

- Más vélemények szerint a szelektív mutizmus hátterében állhat a túl szoros anyagyermek kapcsolat is, illetőleg a mintakövetés. Elképzelhető, hogy más családtag (akár éppen az édesanya) is használja „fegyverként” a hallgatást egyes élethelyzetekben. A szakirodalomban még olyan súlyos állítást is találhatunk, hogy ezek a családok néha nem is érdekeltek a tünet feloldásában. Az anyának sokszor jobb is, ha megtarthatja gyermekét ebben az önállótlan helyzetben - hiszen így palástolhatja saját megoldatlan dependenciaigényét, amely fakadhat saját korábbi szülö-gyermek kapcsolati zavaraiból, vagy aktuális házasságával kapcsolatos elégedetlenségéből. Ezek az édesanyák - bármilyen furcsán hangzik is - tudattalanul 
örülnek ennek a kiváltságos helyzetnek, amelyben gyermekük (beszédével) őket részesíti előnyben (Sarkadi és Kóri, 2005). Az ilyen feltételezések természetesen csak nagy óvatossággal érvényesíthetők a konkrét esetekben.

- Élnek elképzelések arról is, hogy a szelektív mutizmus kialakulásának oka a korai anya-gyermek kapcsolat zavarában, esetleg a beszédfejlődés kezdetének időszakában bekövetkezett pszichés traumában gyökerezik (a gyermek megmarad a nembeszélő csecsemő szerepében).

- Állhat a tünetek hátterében valamilyen kora gyermekkori orális trauma is (pl. a gyermek száját, fogait érintő fizikai sérülés).

- Érdekes gondolat, mely szerint a szelektív mutista gyermek hallgatásának hátterében valamilyen családi titok „megvédése” lapul (inkább nem szólal meg, nehogy véletlenül valami kicsússzon a száján). A titok persze nagyon sokrétü lehet. Nem biztos, hogy a szülők által ténylegesen titokban tartott dologról van szó, hanem előfordulhat, hogy a gyermek titokként értelmez valamit: azt gondolja, hogy erről vagy arról nem szabad beszélnie - lehet ez pl. egy családi betegség, vagy valamilyen jelenet, ami a szülök között zajlott, stb. (Bárdos, 2005).

- Végezetül: a tünet kialakulásában és fenntartásában fontos szerepe lehet a szégyennek is. Előfordulhat, hogy az édesanya egyfajta alárendelt szerepet tölt be a család dominanciarendszerében, így gyermekének sem tud erős támasza lenni. Ilyenkor a gyermek az édesanyjával azonosul. Nemcsak a beszédjét szégyelli, hanem minden életmegnyilvánulását.

- Az eddigi felsorolásból következik, hogy a zavar kialakulásának okáról nincs általánosítható biztos tudásunk.

\section{A SZELEKTÍV MUTISTA GYERMEKEK TÁMOGATÁSÁNAK LEHETŐSÉGEI}

Amikor azt a kérdést tesszük fel, hogyan segíthetnénk egy szelektív mutista gyermeken (akár szülőként, akár pedagógusként), először is tisztáznunk kell, miben/mihez is kívánunk neki segítséget nyújtani, illetve, hogy ténylegesen neki (csak neki) van-e szüksége a támogatásra. Elgondolkodtatóak lehetnek a francia pszichoanalitikus-nyelvész gondolatai, aki szerint: „... a beszéd nem jelent önmagában célt. A pszichés egészség szükséges, de nem elégséges feltétele. (...) a beszéd fejlődéséhez alapvetően arra van szükség, hogy vágyjak a másikkal való kapcsolatra (Danon-Boileau, 2007, 41)". Ugyanis: nem lehet eléggé hangsúlyozni, hogy ezeknél a gyerekeknél nem a kiejtésbeli nehézségek állják útját a beszédnek. A szelektív mutista gyermek tud beszélni, de bizonyos körülmények között nem hajlandó és/vagy nem képes.

Nem vágyik a másikkal/másokkal való kapcsolatra...

A segítő (szülö, pedagógus, terapeuta) talán akkor jár el helyesen, ha nem azt kérdezi, hogy a gyermek miért nem beszél, hanem azt, hogy miért nem vágyik a kapcsolatra! Az elmondottak tükrében a szelektív mutizmusban szenvedő gyermek megsegítésekor ezt a célmeghatározást tartjuk helyénvalónak: a vágy felkeltése a gyermekben a külvilág felfedezése iránt, a vágy felélesztése a másikkal való kapcsolatra. Ebben a koncepcióban pedig nem hagyhatók figyelmen kívül a gyermek szülei, családtagjai sem: egyrészt a segítő részéről ki kell alakítani velük egy jó hatásfokú együttműködést, másrészt figyelembe kell venni, hogy esetleg ők maguk is segítségre szorulnak.

A szelektív mutizmus kezelési protokolljában alkalmazott pedagógiai módszereket és terápiás törekvéseket ismét röviden pontokba szedjük:

- Általános hozzáállás a szelektív mutista gyermekekhez, hogy nem várunk tőlük beszédet, nem erőltetjük őket (legalábbis a kapcsolatunk elején). Hagyjuk, hadd alakuljon ki közöttünk egy kölcsönös elfogadáson és bizalmon alapuló ismeretség. 
- Szintén sokan voksolnak amellett a magatartás mellett, hogy lehetőleg ne árasszuk el szózuhataggal a gyermeket. Hallgassunk együtt. A szavakon túl lépjünk egymással kapcsolatba. Érezze a gyermek, hogy szavak nélkül is értjük öt. A csend is „hallható” (Ksuz, 2005): ha pl. csendben, egymás mellett ülve, együtt nézünk egy tárgyat, az lehetővé teszi, hogy ugyanarra a dologra gondoljunk.

- Bevezethetünk bizonyos rituálékat a közös foglalkozásaink menetébe - ezek a megszokottság, jól ismertség, biztonság érzetét kelthetik a gyermekben, aki a biztonságos közegben egy idő után elkezdheti otthon érezni magát. Ezen a ponton egyszer csak meg lehet zavarni a rítust - $\mathrm{s}$ kíváncsian várni, vajon a gyermek hogyan reagál. Talán jelzi majd, hogy térjünk vissza a megszokott dolgainkhoz? Ez esetben lehet feszegetni a határokat a tekintetben, hányféle ,ajtót” hagyunk számára nyitva ehhez a jelzéshez.

- Gyakran segíthet, ha a szelektív mutista gyermekekkel suttogva beszélünk.

- Azokkal, akik ugyan nem beszélnek, de együttmüködnek velünk, lehetőségünk van együtt játszani. Rajzolni. Bábozni. Építeni. Ilyenkor a gyermek játékával kifejezett tények „beszélnek” a gyökerekről, a miértekről, és ezek a jelzések hasznos iránymutatást képezhetnek számunkra. Az így nyert információkból kiindulva, játékos keretek között, megtaníthatjuk a gyermeket arra, hogyan lehet a játék segítségével megoldást találni bizonyos élethelyzetekre, rossz érzésekre, hogyan lehet azokat módosítani stb.

- Súlyosabb esetben szükség lehet gyógyszeres segítségre. Ha abból indulunk ki, hogy a szelektív mutizmus egyfajta szociális fóbia, s tudvalevő, a fóbiás betegségeken eredményesen segítenek bizonyos, részben szorongáscsökkentő, részben SSRI (hangulatjavító hatású) gyógyszerek, jogos elvárásaink lehetnek a gyógyszeres kezeléstől. A gyógyszeres terápia kiválasztása a gyermekpszichiáterek feladata.

- Végül, de nem utolsósorban említést érdemel a családterápia lehetősége is. Ennek lehet pl. olyan célja, hogy a család ismerje fel és változtassa meg azokat a szokásokat, amelyek a gyerek tünetét fenntartják (pl. ne beszéljenek a gyerek helyett). A statisztikai visszajelzések nagyon biztatóak: arról számolnak be, hogy a gyerekek ilyenkor meggyógyulnak, nem esnek vissza és nem alakítanak ki újabb tüneteket (Sarkadi és Kóri, 2005).

\section{SAJÁT KUTATÁSUNK BEMUTATÁSA: ANYAG, MÓDSZER, KÍSÉRLETI SZEMÉLYEK}

Online-kérdőíves formában olyan édesanyákat kerestünk meg, akik tipikus nyelvi fejlődésü, illetve olyanokat, akik szelektív mutista, 3-12 éves kor közötti gyermekeket nevelnek. A kutatás Magyarországon, kizárólag magyar anyanyelvü (egynyelvű) családok körében zajlott. Összesen 93 kitöltött kérdőívet kaptunk, amelyből 44 anyuka tipikus nyelvi fejlődésű, 49 anyuka pedig szelektív mutista gyermeket nevel. Kutatásunk célja a szelektív mutizmus kialakulási hátterének vizsgálata volt.

Hipotetikusan azt gondoltuk, a szelektív mutizmus kialakulásának hátterében a jelenlegi szakirodalmak szerint feltételezett tipikus nevelöi, környezeti faktoroknál különbség fog mutatkozni a két csoport eredményei között. Feltevésünket azokra a szaporodó tudományos eredményekre alapoztuk, amelyek egyre inkább bizonyítják, hogy a hozott-genetikai információ kibontakozása nem feltétlenül elkerülhetetlen, ugyanis a környezeti tényezők, pl. a nevelési faktorok ezeknek a paramétereknek a beállítódásán sokat változtathatnak. Ezt az elméletet pl. az alábbi kutatás is alátámasztja: Egy állatkísérletben a speciálisan kitenyésztett egereket két csoportra osztották. Az egyik csoportba bátor, felfedező, jól tájékozódó, a másikba félénk, új környezetben elővigyázatos, nehezen tájékozódó egerek kerültek. Az egéranyák embrióit fogantatásuk után néhány nappal mütéti eljárással megcserélték a két 
csoport tagjai között. Azaz: a bátor anyák hordták ki a félénk anyák utódait, és fordítva. Amikor a kisegerek megszülettek, a kutatók nyomon követték a fejlődésüket, viselkedésüket. Azt találták, hogy az utódok a vemhességet kihordó anyák viselkedését mutatták, nem pedig a genetikai sajátosságokat (Andrek, 2012). Kíváncsiak voltunk, hogy a szelektív mutista gyermekeket nevelő szülők körében kimutatható-e valamelyik tipikus attitüd, viselkedésminta.

Kérdéseinket úgy fogalmaztuk meg, hogy a lehető legegyszerübb és legegyértelmübb módon, igen-nem válaszadási lehetőségekkel lehessen rájuk reflektálni. A kérdések összeállításához figyelembe vett elméleteket 6 kategóriába soroltuk. Minden kategóriához 7-7 kérdést rendeltünk hozzá (a 6. pontban ez számszerüen 9-ben jelenik meg, de valójában itt is 7 témát fedtünk le), hogy az arányokat kiegyenlítetten tudjuk tartani. Ezek a következők voltak:

A szociális fóbia egy megnyilvánulási formája (Black és Uhde, 1992)

$\mathrm{Az}$ elsőként feltételezett oki háttér esetében a kutatók a szelektív mutizmust egy tágabb kategória, a szociális fóbia részének tartják. Ennek okaként feltételezhető az öröklés szerepe és/vagy egy viselkedésminta követése is, melyek differenciálása meghaladja a kutatásunk kereteit. (Például ikervizsgálatokra nem volt lehetőségünk.) Az ide tartozó kérdések a következők voltak:

1. Családunkban volt vagy van: szelektív mutista (aki csak bizonyos helyzetekben vagy személyekkel beszél) / szociális fóbiás (aki irracionális félelmet él át társas helyzetekben, ezért inkább kerüli is őket) / egyéb szorongásos betegséggel diagnosztizált személy. (Ha a felsoroltak közül legalább az egyik igaz, akkor Igen-nel feleljen!)

2. Családunkban volt vagy van: tipikusan keveset beszélö, visszahúzódó személyiségtípus.

3. Családunkban volt vagy van: tipikusan bőbeszédü, jó kedélyü személyiségtípus.

4. Ön szeret-e beszélni, beszélgetni társas (közösségi) helyzetekben?

5. Jellemzö-e gyermekére otthoni környezetben a makacs engedetlenség?

6. Jellemzö-e gyermekére idegen környezetben a makacs engedetlenség?

7. Előfordult-e Önnel gyermekkorában, hogy a családon kívül, idegenek elött félt megszólalni?

\section{Rögzült szeparációs szorongás}

Feltételezhetőnek gondoltuk, hogy a szelektív mutista gyermekekben esetleg rögzül, amint bizonyos félelemkeltő helyzetekre hallgatással reagálnak. Tudjuk, hogy a szeparációs szorongás 8 hónapos kortól tipikus (normális) jelenség kb. 3 éves korig. Fontos létfenntartó funkciója, hogy a gyermek az anya közelében, védettség alatt maradhasson, s ahogy egyre több szociális helyzettel találkozik, később majd önállóan is megtanul bánni velük. Elképzelhető, hogy ezt a képességet a mutista gyermek nem szerzi meg. Mivel anyukája is „gyenge lábakon áll”, nem tud egy stabil hátteret nyújtani neki az önállósodáshoz, így a gyermek sem fizikailag, sem pszichésen nem tud leválni, kvázi megmarad a nem beszélő csecsemő szerepében. Ezt a lehetséges tünetkiváltó hátteret a következő kérdések feltevésével jártuk körül:

8. Tud-e/képes-e Ön egyedül lenni?

9. Szorongónak nevezné-e magát?

10. Gyakran vitte-e gyermekét csecsemő- és kisgyermekkorában gyerekközösségekbe?

11. Gyakran hagyta-e idegenekkel (akár a külön háztartásban élő nagyszülőkkel vagy más rokonnal) gyermekét 0-3 éves kora között?

12. Rendszeresen, szinte minden nap sikerül - ha csak rövid időre is - együtt lennem és minőségi időt töltenem a gyermekemmel. 
13. Rendszertelenül: a hét különböző napjain, különbözö mértékben sikerül együtt töltött minőségi időt kigazdálkodnom a gyermekemmel.

14. Szorongok, ha gyermekemtől távol kell lennem.

Túl szoros anya-gyermek kapcsolat (az anya dependenciazavara)

15. Előfordul, hogy a gyermekemmel történt eseményekről többes szám első személyben beszélek (pl. "Bárányhimlösök voltunk.").

16. Jellemző rám, hogy intenzíven igénylem a párom közelségét (olykor talán úgy tünik, "megfojtom" a szeretetemmel), és/vagy a sérelmeimet katasztrofizálom.

17. Inkább távolságtartó, érzelmileg nehezen megközelíthető vagyok.

18. Hangulatember vagyok.

19. Túlféltő/aggódó szülő vagyok.

20. Következetes szülőnek tartom magam.

21. Előfordult, hogy szüleim/nevelöim bántalmaztak gyermekkoromban. (Akár verbálisan, azaz szavakkal, akár testi fenyítéssel.)

Mintakövetés: fegyver/szégyen (Sarkadi és Kóri, 2005)

Feltételezhető, hogy a szelektív mutista gyermek édesanyja (vagy valaki más a családban) fegyverként használja a nem beszélést (pl. az édesanya egy konfliktus kapcsán azzal bünteti a férjét, hogy bizonyos ideig nem szól hozzá). A gyermek előbb-utóbb következetesen ráébred, milyen erő ez az illető kezében, és átveszi ezt a viselkedésmintát. Lehetséges továbbá a másik véglet is, például, hogy az anya maga is kiszolgáltatott a családban, gyerek-szerepben van. Előfordulhat, hogy őt magát is rendszeresen megszégyenítik bizonyos megnyilvánulásaiért, pl. a beszédjéért. A gyermek átveheti az anyának ezt a szégyenérzetét. Ezekre a lehetséges tünetkiváltó környezeti/viselkedéses faktorokra a következőképpen kérdeztünk rá:

22. Előfordul, hogy konfliktus esetén azzal büntetek valakit (pl. a férjem), hogy bizonyos ideig nem szólok hozzá.

23. Előfordul, hogy konfliktus esetén azzal büntetem gyermekem, hogy bizonyos ideig nem szólok hozzá.

24. Elő szokott fordulni, hogy megszólnak (kinevetnek/megaláznak...) azért, ahogyan beszélek/amit mondok.

25. Elő szokott fordulni a családban, hogy gyermekemet nyilvánosan kinevetik/megszégyenítik azért, ahogyan beszél/amit mond.

26. Meg szoktam dicsérni gyermekemet azért, ahogyan beszél vagy amit mond.

27. Gyakran olvastam vagy mondtam (fejből) mesét a gyermekemnek 0-6 éves kora között.

28. Rendszeresen, minden nap beszélgetünk a házastársammal (pl. a napi történésekröl, terveinkről, érzéseinkről stb.).

Családi titok megvédése (Bárdos, 2005)

29. Családunkban van valamilyen, a gyermek elött elhallgatott titok.

30. Családunkban van valamilyen, a gyermek elött is ismert/kimondott titok.

31. Családunkban el szokott hangzani ilyen vagy hasonló kijelentés: "Ne a gyerek előtt!"

32. Előfordul, hogy egyes felnőtt beszélgetések közben rászólunk a gyerek(ek)re, hogy menjen(ek) ki a szobából.

33. Előfordul, hogy ilyet mondunk a gyermekünknek: "Erről másnak nem szabad beszélni, ugye, tudod?"

34. Gyakran mondom gyermekemnek: "Ezt meg ne halljam még egyszer!"

35. Családunkban nyíltan kommunikálunk, nincsenek titkaink egymás előtt. 
Korai pszichés vagy orális trauma

36. Gyermekemet 0-3 éves kora között érte pszichés trauma (akár csak olyan formában, hogy fültanúja volt hangos veszekedéseknek).

37. Gyermekemet 3-7 éves kora között érte pszichés trauma (akár csak olyan formában, hogy fültanúja volt hangos veszekedéseknek).

(A 36. és 37. kérdések közül csak az egyik választ számítottuk be.)

38. Gyermekemet 0-2 éves kora között érte olyan baleset, amelynek során megsérült a szája (vagy a fogai, vagy az arca).

39. Gyermekemet 2-7 éves kora között érte olyan baleset, amelynek során megsérült a szája (vagy a fogai, vagy az arca).

(A 38. és 39. kérdések közül csak az egyik választ számítottuk be.)

40. Várandósságom alatt komoly pszichés megterhelésben volt részem (pl. gyakori családi veszekedés, baleset stb.).

41. Várandósságom alatt sokat beszéltem/meséltem/énekeltem a babámnak.

42. Várandósságom utolsó trimeszterében előfordult, hogy (ha csak rövid időre is) túl erős hanghatásnak/zajnak voltam kitéve.

43. Gyermekem 2 éves kora elött volt olyan eset, hogy hosszabb időt (pl. néhány napot) távol kellett töltenünk egymástól (pl. kórházba kerülés vagy más eset miatt).

44. Gyermekem első 3 életéve alatt sok családi veszekedésben volt részem.

\section{EREDMÉNYEK, KÖVETKEZTETÉSEK}

A vizsgálatban részt vevő gyerekek között a nemek aránya (teljesen véletlenül) nagyjából kiegyenlítettnek mondható (1. ábra), ami megkönnyíti a vizsgált és a kontrollcsoport eredményeinek összehasonlítását: a vizsgált szelektív mutista gyermekek fele lány, fele fiú, a tipikus nyelfejlődésủek között 59\%-ban lányok, 41\%-ban fiúk vannak jelen.

1. ábra: A vizsgált gyerekek nemek szerinti százalékos megoszlása, Forrás: Szerző.

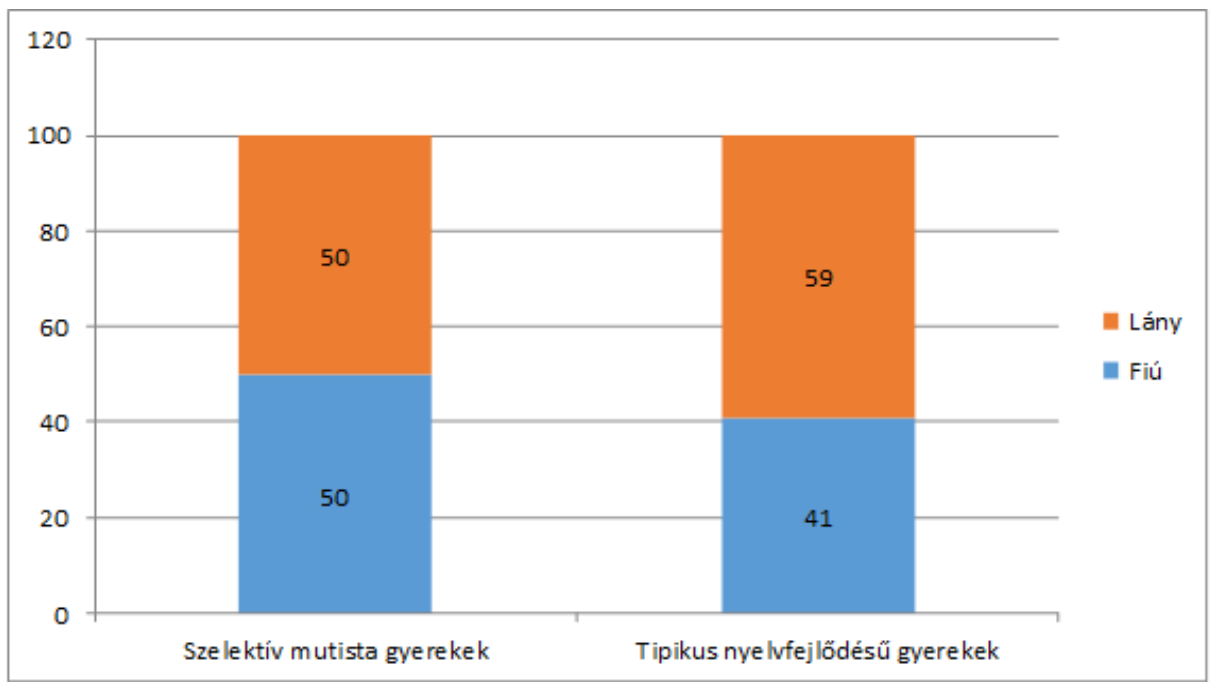

A két csoport eredményei (mind a 6 feltételezett oki hátteret, valamint mind a 44 kérdésre adott választ áttekintve) egymáshoz viszonyítva összességében azt mutatják, hogy a szelektív mutizmus kialakulásának hátterében többnyire a hozott faktorok (az 1., 2., 3. oki háttércsoport) játszanak szerepet. Ezen belül azonban továbbra is nyitott kérdés, hogy öröklött 
(genetikai) tényezőkről, vagy viselkedéses mintakövetésről lehet-e beszélni (mint családi „hozományról”).

A legszembetünőbb eltérést az 1. kérdésre adott válaszoknál kaptuk (2. ábra). Látható, hogy a szelektív mutista gyermekek felmenői között több mint kétszer nagyobb arányban fordul(t) elő diagnosztizált szelektív mutizmus, szociális fóbia vagy egyéb szorongásos megbetegedés.

2. ábra: A szelektív mutizmus családi elöfordulása (1. kérdés) - százalékos gyakoriság. Forrás: Szerzö.

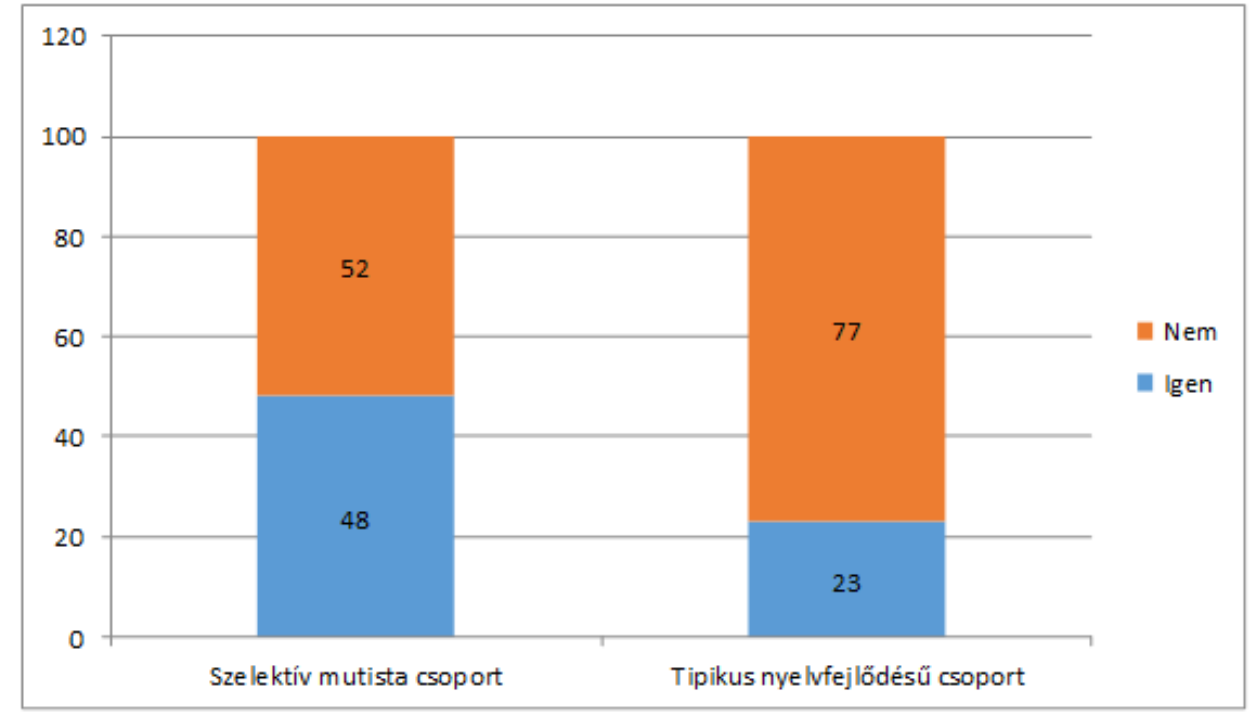

A tipikusan keveset beszélő, inkább visszahúzódó személyiségtípusok családi előfordulása is magasabb a szelektív mutista gyerekek rokonainak körében: 80\%-os (a tipikus nyelvfejlődésü csoport 45\%-ával szemben). Ugyan ezek a válaszok nem szakvéleményeken, hanem a kérdőívet kitöltő édesanyák szubjektív megítélésén alapulnak, mindenképpen figyelmet érdemelnek (1. 3. ábra).

3. ábra: Tipikusan visszahúzódó, keveset beszélö személyiségtípus százalékos előfordulása a családban (2. kérdés). Forrás: Szerzö.

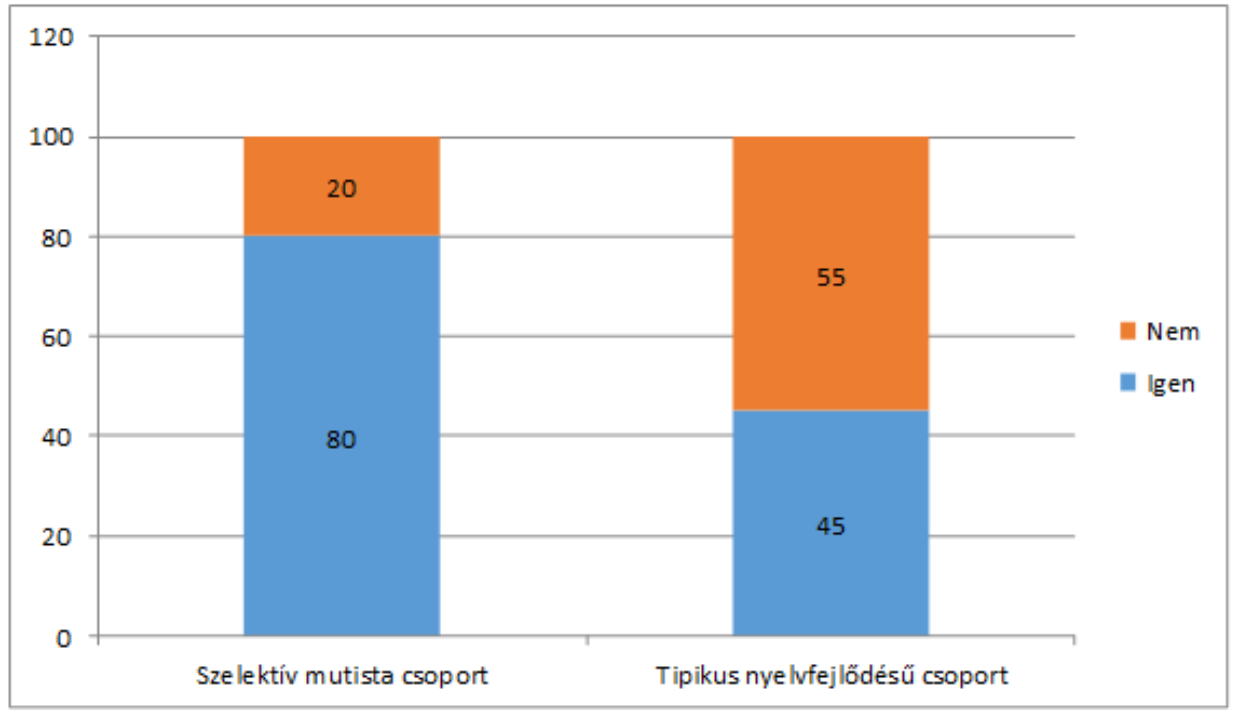

A szelektív mutista gyermekek a tipikusan visszahúzódó, kevésbeszédű családtagok beszédviselkedés-mintáját is könnyen eltanulhatják, még nagyobb azonban az esélye annak, hogy az ugyanilyen tulajdonságokkal rendelkező édesanyjuk lesz rájuk nagy hatással (1. 4. 
ábra). Ebből a szempontból a kutatás alátámasztani látszik azt a hipotézist, miszerint a fejlödés során a környezet viselkedésének kiemelkedő szerepe van a gyermek beszédfejlődésének alakulására, hiszen látható, hogy a szelektív mutista gyermekeket nevelő édesanyák maguk sem szívesen beszélgetnek társas helyzetekben (41\%-uk sorolta magát ebbe a kategóriába, szemben a tipikus fejlődésü gyermekek nevelőinek 12\%-ával). Tehát: eredményeink inkább azt az elképzelést támogatják, miszerint a genetika adja a „lehetőséget”, azonban a környezet az, amely kibontakoztat.

4.ábra: A gyermek édesanyja szeret-e beszélgetni társas helyzetekben? (4. kérdés) Százalékos gyakoriság. Forrás: Szerzö.

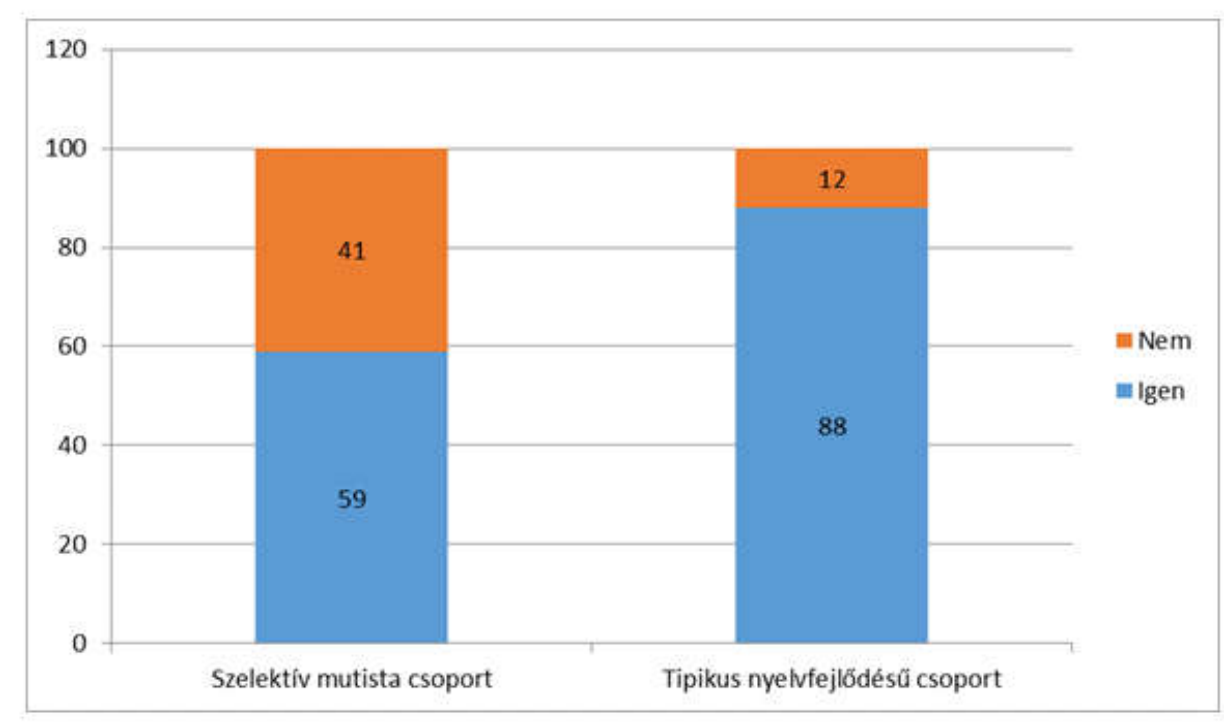

A szelektív mutista gyermeket nevelő édesanyákról ugyanakkor az is valamivel nagyobb arányban mondható el, hogy gyermekként maguk is küzdöttek beszédfélelemmel (5. ábra).

5.ábra: Elöfordult-e gyermekkorában, hogy idegenek elött félt megszólalni? (7. kérdés). Százalékos gyakoriság. Forrás: Szerzö.

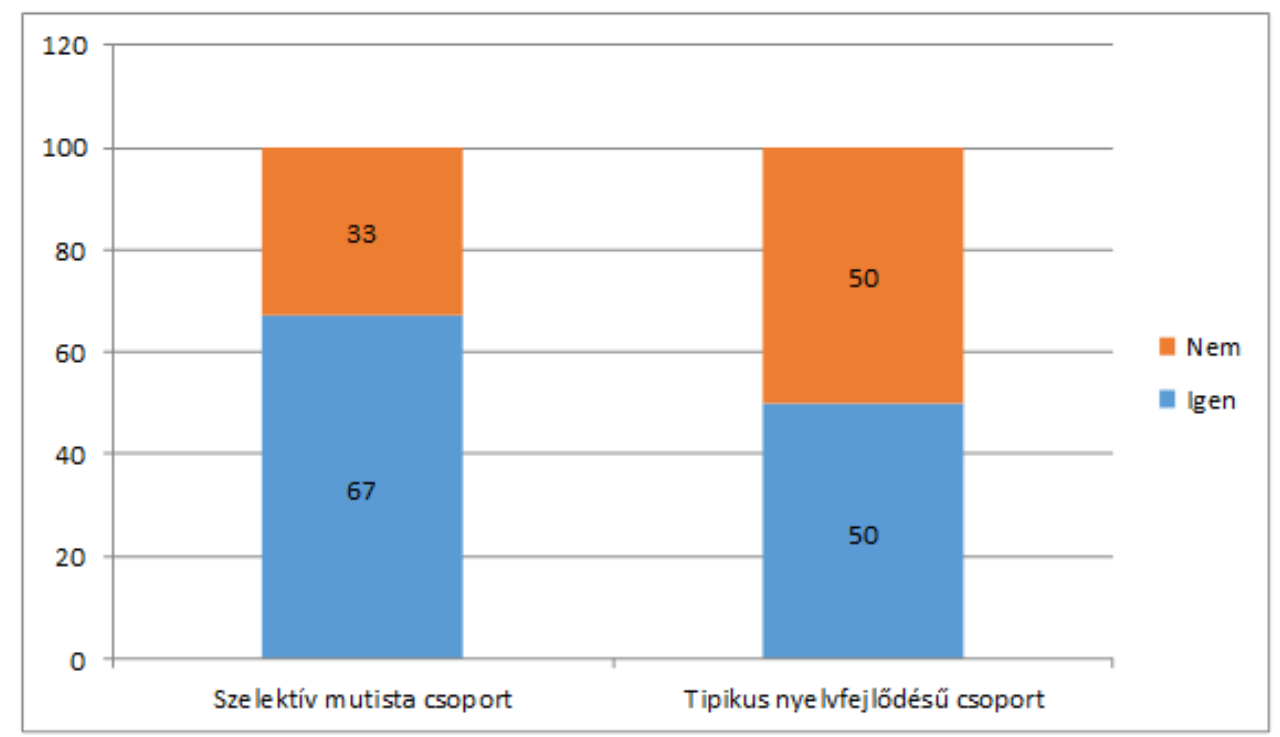

A szelektív mutista gyermekeket nevelő édesanyák saját bevallásuk szerint a mai napig (55\%-os arányban) szorongó típusúnak tartják magukat (6. ábra), valamint érzelmileg 
majdnem kétszer akkora mértékben távolságtartóbbnak, nehezen megközelíthetőbbnek, mint a tipikus nyelvfejlődésű gyermekeket nevelő anyukák (7. ábra). Ezek az adatok szintén alapot adhatnak ahhoz, hogy a szelektív mutizmus kialakulása mögött mintakövetési hajlandóságot feltételezzünk.

6. ábra: Ön szorongónak nevezné-e magát? (9. kérdés). Százalékos gyakoriság. Forrás. Szerzö.

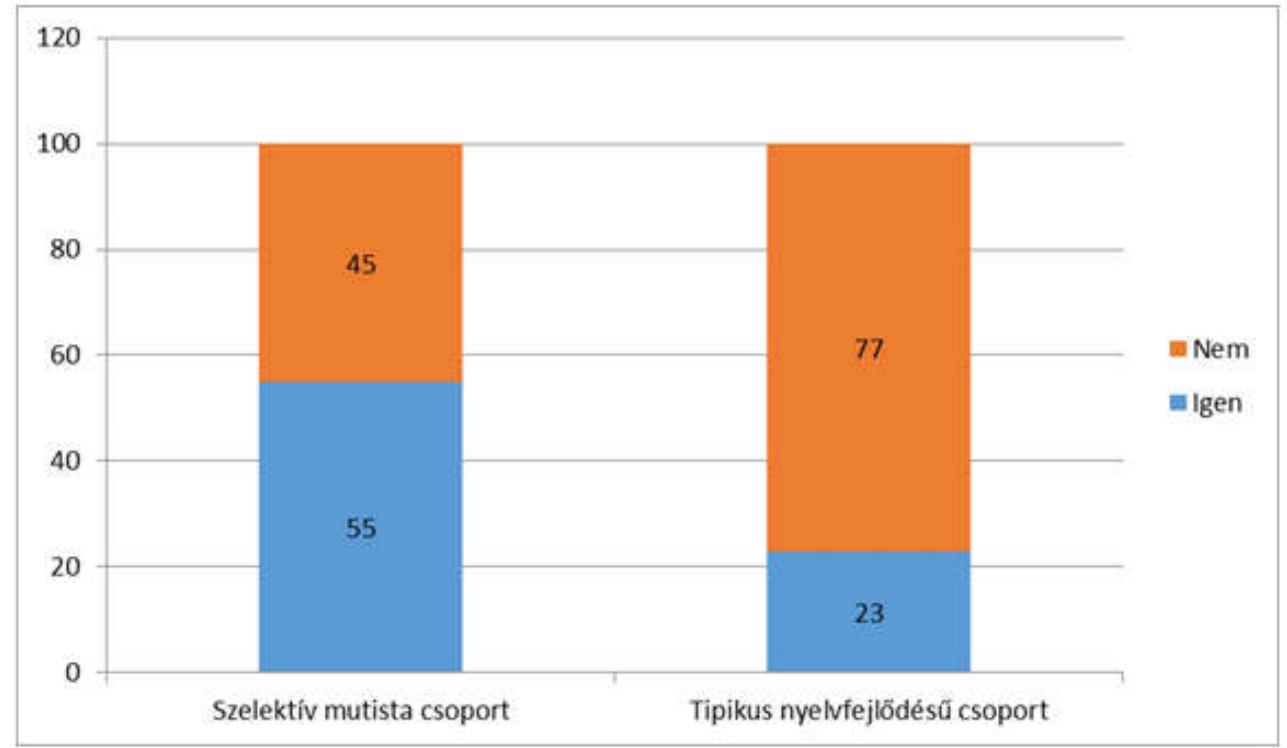

7.ábra: Inkább távolságtartó, érzelmileg nehezen megközelíthetö édesanya (17. kérdés). Százalékos gyakoriság. Forrás. Szerzö

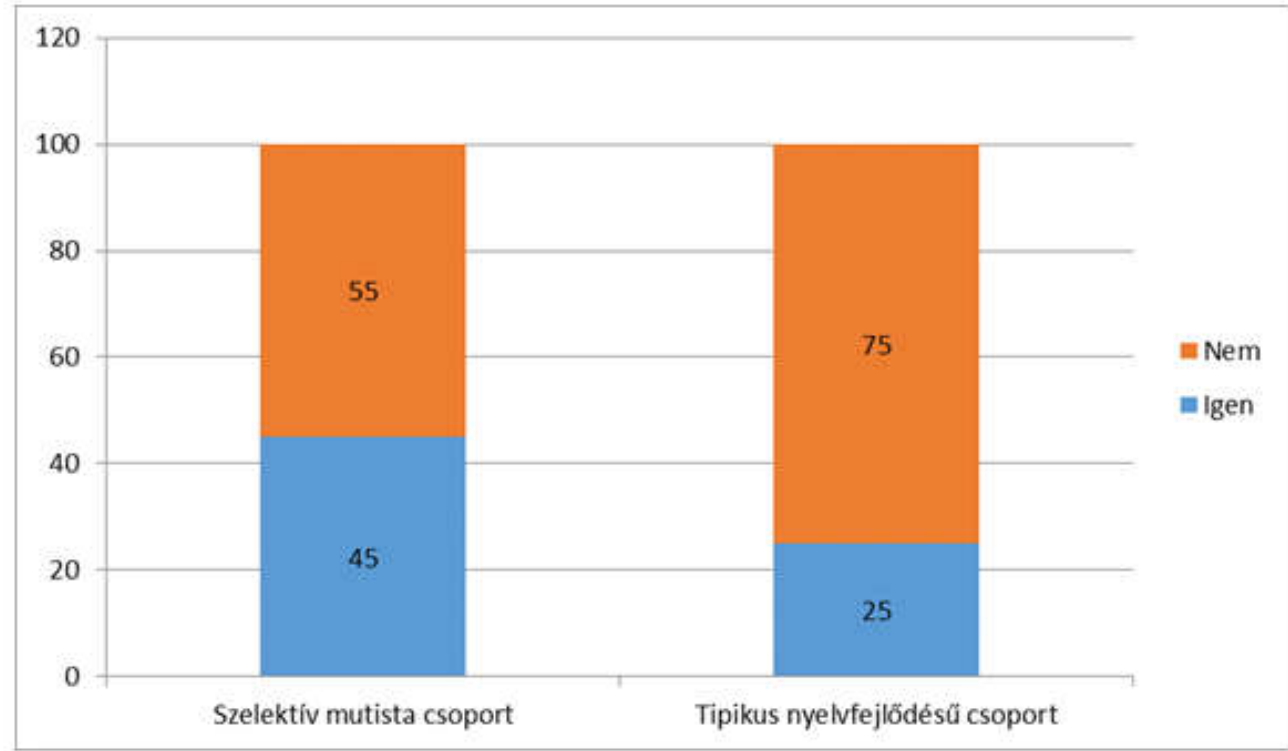

A kutatás eredményei a (beszédviselkedéses) mintakövetésen kívül rámutatnak arra is, hogy a szelektív mutista gyermeket nevelő édesanyák - dacára annak, hogy saját bevallásuk szerint inkább túlféltő, aggódó anyukák - rendszertelenebb módon tudnak minőségi időt együtt tölteni gyermekükkel (8. ábra), továbbá saját magukat következetlenebb szülötípusnak tartják, mint a tipikus nyelvfejlődésü gyerekeket nevelő édesanyák (9. ábra). 
8. ábra: Rendszertelenül kigazdálkodott minőségi idő (13. kérdés). Százalékos gyakoriság. Forrás. Szerzö.

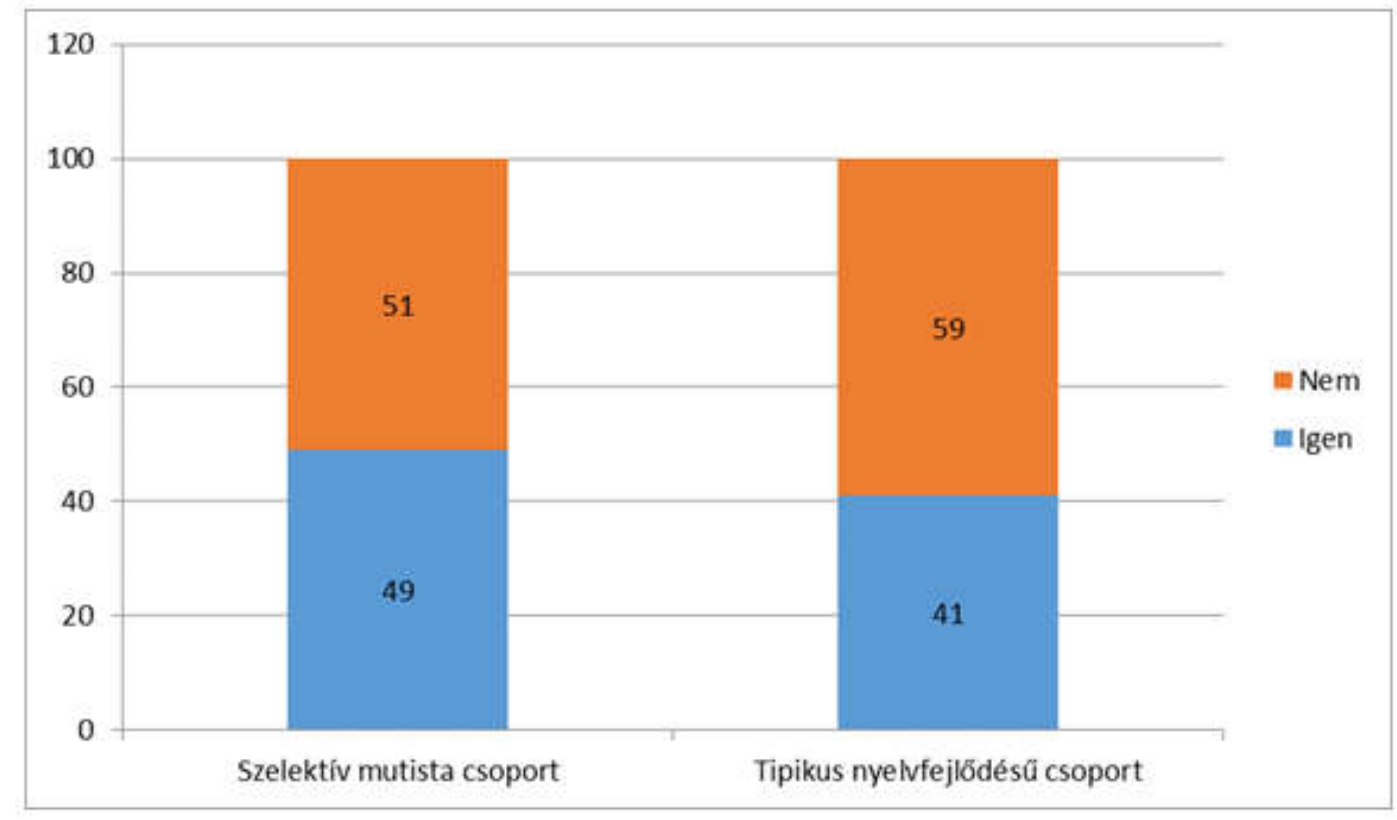

9. ábra: Következetes szülőnek tartom magam (20. kérdés). Százalékos gyakoriság. Forrás: Szerzö.

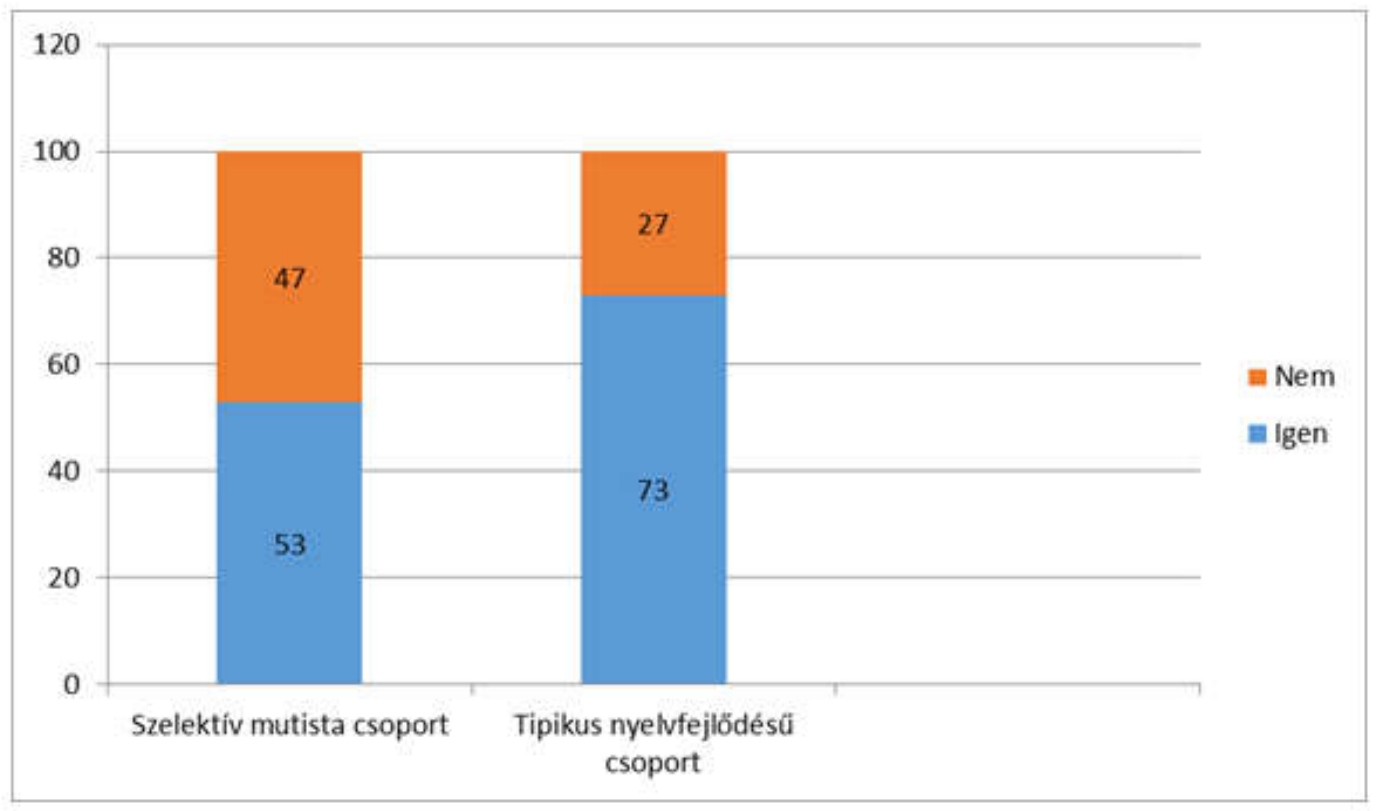

Saját kutatási eredményeink összességében arra engednek következtetni, hogy a szelektív mutista gyermekek egyfajta beszédviselkedés-mintát vesznek át elsődlegesen a családtagjaiktól, tüneteik pedig leginkább a szociális fóbiával érintkeznek. Ennek háttere lehet genetikai, de elképzelhető, hogy genetikától függetlenül - mivel erre vonatkozó adatok nem állnak rendelkezésünkre - az édesanya (vagy más családtag) szorongásából fakadó speciális viselkedésének a hatása a döntő, továbbá az édesanya saját dependenciazavarának áttétele. Az 
azonban nem igazolódott, hogy az érintettek családjában valaki fegyverként használná a beszéd megtagadását, ahogyan az sem, hogy ezeknek a gyerekeknek az édesanyját bármilyen beszéddel kapcsolatos megnyilvánulásáért nyíltan vagy burkoltan módszeresen megszégyenítenék. Szintén nem nyert alátámasztást, hogy a szelektív mutista gyerekek valamilyen családi titkot igyekeznének megvédeni. A koragyermekkori traumák elszenvedése is közel azonos arányban volt jellemző mindkét csoportra, bár 3-7 éves kor között a szelektív mutista gyerekek ezen a téren valamivel nagyobb számban érintettek (44\%-kal, a tipikus csoport 36\%-os eredménye mellett).

\section{ÖSSZEGZÉS}

Mivel az általunk felvett, számszerüen hatféle feltételezett oki háttér közül az első három kategória kérdéseire adott válaszok hozták ki a legnagyobb különbségeket a tipikus és a szelektív mutista gyermekeket nevelő édesanyák között, a segítői attitüd szempontból ezeken a tényezőkön érdemes elgondolkodni:

- a szelektív mutista gyermekek beszédmegtagadása egyfajta szociális fóbiaként is értelmezhetö,

- melynek hátterében állhat rögzült szeparációs szorongás,

- valamint az édesanya dependenciazavarának áttétele.

Saját kutatási eredményeink alapján elmondható, hogy a szelektív mutista gyermekeket tanító pedagógusok személyisége és kommunikációs stílusa is alapvető mintaértékkel bírhat. Még pontosabban: a segítőnek arra kell törekednie, hogy felülírja az otthonról hozott, rögzült sémákat. Miközben a segítö/pedagógus megmutatja, hogy lehet nemcsak a gondolatokról, hanem az érzelmekről is nyíltan és öszintén kommunikálni, fontos, hogy beszédviselkedését is mindig következetesség jellemezze. A rendszeres közvetlen kommunikáció és következetes magatartásminta (gyermekek és felnőttek irányába egyaránt) elengedhetetlen háttérbázisa lehet a beszédfélelemmel küzdő gyerekekkel való bánásmódnak.

\section{IRODALOM}

Andrek, A. (2012). A magzat üzenete - Kommunikáció és kapcsolat. Mindennapi Pszichológia 2012/6: 40-44.

Bárdos, K. (2005). „Neked már nem is kell, hogy szájad legyen”. Fordulópont 2005: 13-16.

Black, Bruce és Uhde, Thomas W. (1992). Elective mutism as a variant of social phobia. Journal of the American Academy of Child and Adolescent Psychiatry 31: 1090-1094.

BNO-10 zsebkönyv (2004). Budapest: Animula Kiadó.

Danon-Boileau, Laurent (2007). A gyermek, aki nem beszélt. Budapest: Pont Kiadó.

Gósy, M. (2005). Pszicholingvisztika. Budapest: Corvina Kiadó.

Hernádi, K. (2006). Inkluzív nevelés - Ajánlások beszédfogyatékos gyermekek kompetencia alapú fejlesztéséhez. Budapest: SuliNova Közoktatás-fejlesztési és Pedagógustovábbképzési Kht.

Illyés, S. (2000). Gyógypedagógiai alapismeretek. Budapest: ELTE BGGyF.

Ksuz, Sz. (2005). A csend hangjai. Fordulópont 2005: 65-69.

Kuncz, E. (2007). A szelektív mutizmus felismerése. A tünetegyüttes differenciáldiagnosztikai feldolgozása két eset tükrében. Budapest: Oktatási és Kulturális Minisztérium.

Nussbaum, Abraham M. 2013. A DSM-5 diagnosztikai vizsgálat zsebkönyve. Budapest: Oriold és Társai Kiadó és Szolgáltató Kft.

Ranschburg, J. (2005). Pszichológiai rendellenességek gyermekkorban. Budapest: Nemzeti Tankönyvkiadó.

Sarkadi, B. és Kóri, M. (2005). (Sz)elektív mutizmus. Fordulópont 2005: 5-12. 